\title{
A utoimmune hemolytic anemia and giant cell hepatitis: Report of three infants
}

\author{
Otoimmun hemolitik anemi ve dev hücreli hepatit birlikteliği olan üç \\ olgunun sunumu
}

\author{
Şule Ünal1, Banş Kuşkonmaz1, Necati Balamtekin², Gökhan Baysoy², Selin Aytaç \\ Elmas', Diclehan Orhan³, GülsevKale³, Aysel Yüce², Figen Gürakan², Fatma Gümrük1, \\ Mualla Çetin ${ }^{1}$ \\ 1Division of Pediatric Hematology, Hacettepe University Faculty of Medicine, Ankara, Turkey \\ 2Division of Pediatric Gastroenterology, Hacettepe University Faculty of Medicine, Ankara, Turkey \\ 3Division of Pediatric Pathology, Hacettepe University Faculty of Medicine, Ankara, Turkey
}

\section{A bstract}

Giant cell hepatitis associated with direct Coombs' test-positive hemolytic anemia is a rare condition of childhood and the pathogenesis remains unclear. An autoimmune activation and loss of self-tolerance in these patients may be the underlying pathology related to the response of some of the patients to immunosuppressive treatment. Herein, we report the clinical presentation and course of three consecutive patients with this rare condition. We conclude that serum ferritin at diagnosis may be used for prediction of the outcome. (Turk J Hematol 2010; 27: 308-13)

Key words: Giant cell hepatitis, immune hemolytic anemia, direct Coombs' test, rituximab

Received: May 5, 2010

Accepted: August 19, 2010

\section{Özet}

Direk Coombs' testi pozitif hemolitik anemi ve dev hücreli hepatit birlikteliği çocukluk çağında patogenezi tam olarak aydınlatılmamış nadir bir durumdur. Bu hastaların bir kısmının immünosupresif tedaviye cevap veriyor olması otoimmün aktivasyon ya da kendi antijenlerine karşı tolerans kaybının patogenezde sorumlu olabileceğini düşündürmektedir. Bu makalede bu nadir duruma sahip üç hastanın başvuru özellikleri ve takibi sunulmusstur. Başvuru anındaki serum ferritin değerinin hastanın prognozunu belirlemede kullanılabileceği önerilmiştir. (Turk J Hematol 2010; 27: 308-13)

Anahtar kelimeler: Dev hücreli hepatit, immün pozitif hemolitik anemi, direk Coombs' testi, rituximab 


\section{Introduction}

Giant cell hepatitis (GCH) associated with direct Coombs' test-positive autoimmune hemolytic anemia (AlHA) is a rare, often lethal condition of early childhood with unknown pathogenesis. GCH-AlHA association is a distinct disorder from the more common GCH diagnosed in the neonatal period in association with infections, metabolic disorders and cholestasis [1-4]. Management of these patients is a challenge, carries poor response to immunosuppressive therapy and often progresses to fatal liver disease [1,5]. Tissue autoantibodies have been negative in most cases; however, these patients usually fail to respond to orthotopic liver transplantation compared with other types of $\mathrm{GCH}$ found in children and have a high rate of $\mathrm{GCH}$ recurrence in the transplanted liver. This may suggest the presence of an as-yet undetermined circulating autoantibody $[1,2,6]$.

To our knowledge, 24 cases of GCH with AlHA have been reported [1-17]. The AlHA usually precedes the diagnosis of GCH by 1 week to 15 months (usually 1-2 months), and the hepatitis presents more insidiously $[5,11]$. Herein, we present the clinical presentation and course of three consecutive patients with this rare condition with possible implications as to the etiopathogenesis.

\section{Case Reports}

Table 1 summarizes the clinical and laboratory characteristics of the study group.

\section{Case 1}

A two-month-old girl, the first child of parents with first-degree consanguinity, who presented with pallor was found to have direct Coombs' test-positive hemolytic anemia and was placed on steroid treatment (2-10 mg/kg/day) and intravenous immunoglobulin ( $1 \mathrm{~g} / \mathrm{kg} /$ day, for 2 days; 3 courses) in another center. The patient was transiently responsive to attacks; however, she was found to have cytomegalovirus (CMV) IgM and CMV polymerase chain reaction (PCR) positivity ( $8800 \mathrm{copy} / \mathrm{ml})$ at eight months of age and was placed on ganciclovir treatment. By the $14^{\text {th }}$ day of antiviral treatment, she developed hypertransaminasemia and was referred to our center for further evaluation.
Physical examination revealed a jaundiced girl with body weight $<3^{\text {rd }}$ percentile and height $50-75^{\text {th }}$ percentile. Liver and spleen were palpable $4 \mathrm{~cm}$ and $2 \mathrm{~cm}$ below the costal margins, respectively. The hemogram revealed hemoglobin $(\mathrm{Hb}): 10.3 \mathrm{~g} /$ $\mathrm{dl}$, hematocrit (Hct): $28.9 \%$, white blood cells (WBC): $31.4 \times 10^{9} / L$, thrombocyte: $244 \times 10^{9} / L$, mean corpuscular volume (MCV): $94.1 \mathrm{fl}$, and red cell distribution width (RDW): 26.3. Reticulocytes were 8.6\% and peripheral blood smear exhibited polychromasia, spherocytosis, anisocytosis, poikilocytosis, and normoblastemia. The liver function tests revealed aspartate aminotransferase (AST): 2147 (<37 IU/L), alanine aminotransferase (ALT): 2117 (<41 IU/L), gamma-glutamyl transpeptidase (GGT) 83.3 (5-36 IU/L), alkaline phosphatase (ALP): 949 (<281 IU/L), total bilirubin: $62.7(0.1-1.2 \mathrm{mg} / \mathrm{dl})$, and conjugated bilirubin 62.1 (0-0.3 mg/dl). Serum IgA level was 116 mg/dl (8-80), lgG: 774 mg/dl (220-900) and IgM: $140 \mathrm{mg} / \mathrm{dl}$ (35-125). Viral serologies for hepatitis $A$, hepatitis $B$ and hepatitis $C$ were negative. CMV IgM and IgG were positive and CMV PCR was 951 copy $/ \mathrm{ml}$. Funduscopic examination for CMV infection was negative. Ganciclovir was continued until the result of the liver biopsy was available, which revealed giant cell transformation, portal fibrosis, focal hepatocyte necrosis, lymphocytic infiltration, and hemosiderin accumulation in hepatocytes and Kupffer cells, without any evidence of CMV involvement. The patient was diagnosed to have GCH-AlHA condition, and anti-nuclear antibody, anti-smooth muscle antibody, anti-liver kidney microsomal antibody, and anti-cardiolipin and anti-phospholipid antibodies were found to be negative. Initial serum ferritin was measured as $32078 \mathrm{ng} / \mathrm{ml}$, and subsequently dropped to $4858 \mathrm{ng} /$ $\mathrm{ml}$ by the second week of admission. Serum triglyceride was 547 (<200 mg/dl), cholesterol 132 (<200 $\mathrm{mg} / \mathrm{dl}$ ) and plasma fibrinogen $360 \mathrm{mg} / \mathrm{dl}$. The bone marrow aspiration revealed bi- and tri-nucleated normoblasts indicating erythroid hyperactivity and dyserythropoiesis with increased histiocytes without any evidence of hemophagocytosis.

Treatment was continued with $2 \mathrm{mg} / \mathrm{kg}$ methylprednisolone, and azathioprine ( $1 \mathrm{mg} / \mathrm{kg}$ ) was initiated, in addition to cholestyramine for cholestasis and omega-3 for hyperlipidemia. She developed pneumonia with ground-glass appearance on thorax computed tomography and CMV positivity 
recurred; ganciclovir was re-initiated. During the course, hepatic failure progressed with portal hypertension and ascites, and rituximab (anti CD20) was initiated at $375 \mathrm{mg} / \mathrm{m}^{2} /$ week, concomitant to ganciclovir. The patient died after the $3^{\text {rd }}$ dose of rituximab treatment, with intervening sepsis and hepatic coma, at 17 months of age.

\section{Case 2}

A six-month-old boy presented to our center with pallor and jaundice. The personal history revealed a similar admission to a local hospital at the first month of life. He was thought to have prolonged jaundice and was transfused with packed red blood cells, and a second admission to the same hospital at three months of age with dark stools revealed disturbed liver function tests and prolonged coagulation tests. Antibiotics, fresh frozen plasma and vitamin $\mathrm{K}$ were initiated and the patient was referred to our center at six months of age because of refractory illness.

The patient was the only child of a first-degree consanguineous couple, without history of any sibling death. The physical examination revealed a jaundiced boy with hepatosplenomegaly, palpable $8 \mathrm{~cm}$ and $6 \mathrm{~cm}$ below the costal margins, respec- tively. Body weight and height were 3-10 p. The hemogram revealed $\mathrm{Hb}: 9 \mathrm{~g} / \mathrm{dl}$, Hct: $24.7 \%$, WBC: $6.7 \times 10^{9}$ /L, thrombocyte: $102 \times 10^{9}$ /L, MCV: $87.5 \mathrm{fl}$, and RDW: 16.6. Reticulocyte count was 4.2\%. Direct Coombs' test was positive. The liver function tests revealed AST: $309 \mathrm{IU} / \mathrm{L}, \mathrm{ALT}: 92 \mathrm{IU} / \mathrm{L}, \mathrm{GGT}: 29.9 \mathrm{IU} / \mathrm{L}$, total bilirubin: $25.5 \mathrm{mg} / \mathrm{dl}$, direct bilirubin $15.7 \mathrm{mg} / \mathrm{dl}$, total protein: $5.86 \mathrm{~g} / \mathrm{dl}$, and albumin: $3.67 \mathrm{~g} / \mathrm{dl}$. Activated partial thromboplastin time ( $\mathrm{PPTT}$ ) and prothrombin time (PT) (international normalized ratio [INR]) were $46.6 \mathrm{sec}$ (27.9-38.1) and 1.64 (0.861.2), respectively. Serum IgA was $287 \mathrm{mg} / \mathrm{dl}$ (8-80), IgG: $1100 \mathrm{mg} / \mathrm{dl}$ (220-900) and IgM: 408 mg/dl (35125). Viral serologies for hepatitis $A$, hepatitis $B$ and hepatitis $C$ were negative. CMV IgM and IgG were positive and CMV PCR was 330 copy/ml, and ganciclovir was initiated. Funduscopic examination for CMV infection was normal. The liver biopsy revealed giant cell formation with canalicular and hepatocelIular cholestasis, without any evidence of CMV involvement. Immunohistochemical examination with MDR3 staining excluded the diagnosis of progressive familial intrahepatic cholestasis type 3 . The patient was diagnosed to have GCH-AlHA condition, and anti-nuclear and anti-liver kidney microsomal antibodies were found to be negative. Serum ferri-

Table 1. Characteristics of patients with GCH and AIH A

\begin{tabular}{llll}
\hline & Case 1 & Case 2 & Case 3 \\
\hline Onset of AlHA (mo) & 2 & 1 & 11 \\
Onset of hepatitis (mo) & 8 & 3 & 15 \\
CMV status & + & + & - \\
Ganciclovir therapy & + & 325 & 93 \\
Serum & 32078, & & Methylprednisolone \\
ferritin (ng/ml) & $(4858) *$ & Ursodeoxycholic & Azathioprine \\
Treatment & Methylprednisolone & acid & Rituximab \\
& IVIG & Cholestyramine & Ursodeoxycholic acid \\
& Azathioprine & & Hituximab \\
Cholestyramine & Omega-3 & IgG and IgM levels; & hypogammaglobulinemia \\
Additional problem & High serum IgA & G6PDH deficiency & of infancy \\
\hline
\end{tabular}

* Initial serum ferritin was measured as $32078 \mathrm{ng} / \mathrm{ml}$ and subsequently dropped to $4858 \mathrm{ng} / \mathrm{ml}$ by the second week of admission.

AlHA: Autoimmune hemolytic anemia; mo: month; CMV: Cytomegalovirus; IVIG: Intravenous immunoglobulin; G6PDH: Glucose 6-phosphate dehydrogenase. 
tin was measured as $325 \mathrm{ng} / \mathrm{ml}$. Interestingly, the patient was found to have additional glucose 6-phosphate dehydrogenase deficiency. He was placed on ursodeoxycholic acid and cholestyramine and was discharged for close follow-up; however, it was learned that he died in the $2^{\text {nd }}$ month of discharge in a local hospital.

\section{Case 3}

An 11-month-old male presented initially to another center with pallor and was found to have $\mathrm{Hb}$ of $4.1 \mathrm{~g} / \mathrm{dl}$ with $4+$ direct Coombs' test. It was learned that methylprednisolone $10 \mathrm{mg} / \mathrm{kg} /$ day had been initiated and the dose was tapered off subsequently; however, he had two more attacks during periods of dose reduction of steroid treatment and needed doses as high as $20 \mathrm{mg} / \mathrm{kg} /$ day for hemolysis control. At 15 months of age, while on $2 \mathrm{mg} / \mathrm{kg} /$ day methylprednisolone treatment, he developed vomiting and diarrhea and presented to our center. The family history was unremarkable excluding the second- degree consanguinity between parents. He had three healthy older siblings. The physical examination revealed a jaundiced boy with liver palpable $2 \mathrm{~cm}$ subcostally on the midclavicular line. The hemogram revealed $\mathrm{Hb}: 7.9 \mathrm{~g} / \mathrm{dl}$, Hct: $23.1 \%$, WBC: $12.1 \times 10^{9}$ /L, thrombocyte: $147 \times 10^{9} / \mathrm{L}, \mathrm{MCV}: 93.7 \mathrm{fl}$, and RDW: 18.6. Reticulocytes were 4\%. Direct Coombs' test was positive. The liver function tests revealed AST: $770 \mathrm{IU} / \mathrm{L}, \mathrm{ALT}: 1225 \mathrm{IU} / \mathrm{L}, \mathrm{GGT} 141$ IU/L, total bilirubin: $3.95 \mathrm{mg} / \mathrm{dl}$, direct bilirubin 2.36 $\mathrm{mg} / \mathrm{dl}$, total protein: $5.31 \mathrm{~g} / \mathrm{dl}$, and albumin: $3.33 \mathrm{~g} /$ dl. aPTT and PT (INR) were $30.0 \mathrm{sec}(25-40)$ and $0.96(0.75-1.5)$, respectively. Serum haptoglobulin level was $<5.83 \mathrm{mg} / \mathrm{dl}$ (36-195). Viral serologies for Epstein-Barr virus (EBV), hepatitis $A$, hepatitis $B$, hepatitis $C$, hepatitis $E$, human immunodeficiency virus (HIV) and parvovirusB19 were negative, whereas the patient was immune for hepatitis $B$ related to prior immunization, and he was IgM negative and IgG positive for CMV infection. Serum ferritin was $93 \mathrm{ng} / \mathrm{ml}$. Anti-mitochondrial, antismooth muscle and anti-liver kidney microsomal antibodies were negative. Serum IgA, IgG and IgM were measured as $81 \mathrm{mg} / \mathrm{dl}$ (30-107), $420 \mathrm{mg} / \mathrm{dl}$ (605-1430) and $96 \mathrm{mg} / \mathrm{dl}$ (66-228), respectively, and the low IgG level for age was considered as transient hypogammaglobulinemia of infancy. Ursodeoxycholic acid was initiated and steroid dose was increased up to $10 \mathrm{mg} / \mathrm{kg} / \mathrm{day}$. Liver biopsy revealed fibrosis in the portal areas, giant cell transformation of hepatocytes, intracellular cholestasis, sinusoidal dilatation, and focal areas of extramedullary hematopoiesis, with no evidence of hemosiderin or copper accumulation. Azathioprine was initiated in addition to steroid treatment. During the course, because of the frequent attacks of Coombs'-positive hemolytic anemia, rituximab ( 375 $\mathrm{mg} / \mathrm{m}^{2} /$ week, for four weeks) was started at the 6th month of azathioprine, at the age of 24 months. Steroid was gradually tapered off and azathioprine was continued. This patient is currently alive, free of transfusion, with negative direct Coombs' test and normal liver function tests, after a follow-up of 18 months and completion of four weekly doses of rituximab.

Written informed consent was obtained from patients.

\section{Discussion}

Although GCH-AlHA association was reported more commonly among infants, there are rare reports of late-onset cases, such as in an 18-year-old male who survived after orthotopic liver transplantation [3]. In our series of cases, the patients presented between 1 and 11 months of age with AlHA, which preceded hepatitis by 2-6 months. Case 1 and 3 received immunosuppressive treatment prior to the development of overt hepatitis, which could not prevent the development of the subsequent disease. The presence of consanguinity between parents of all three patients may indicate an underlying inherited immunological defect predisposing these children to this peculiar association.

Giant cell hepatitis (GCH) associated with AlHA has been reported to have mortality rates as high as approximately 50\% [13], and this high mortality has been attributed not only to the severe liver failure or uncontrollable anemia, but also to sepsis related to the aggressive use of immunosuppressive drugs $[6,8,13,17]$. As our cases and the literature data indicate, although this condition carries a high mortality, the clinical spectrum shows some diversity in severity and may respond to steroid alone or in combination with azathioprine $[9,14,15]$. However, there are other reports in which the cases were unresponsive to immunosuppressive therapies and 
required orthotopic liver transplantation. The results of liver transplantation also show variable outcomes, including very early (even within weeks) recurrence of the disease in the transplanted liver $[13,17]$ as well as survival after transplantation $[2,3]$. The post-transplant survivors may also have benefited from the immunosuppressants used during the post-transplantation period.

Recently, there have been promising results with monoclonal antibodies including rituximab or alemtuzumab therapy, which may decrease the requirement for transplantation $[1,4,5]$. The good results with rituximab and recurrence of disease after liver transplantation in the transplanted liver may indicate a circulating as-yet undetermined antibody in these patients. Additionally, the serum immunoglobulin abnormalities in our study group may also indicate an immune dysregulation in these patients. All three of our patients were negative for the autoimmune markers. Two of the patients were CMV PCR-positive and received ganciclovir treatment; however, no accompanying viral agent could be demonstrated in Case 3. This finding may indicate an autoimmune activation and loss of self-tolerance in these patients related to some infections. Camerero Salcés et al. [16] also reported associated CMV infection with this condition.

The presence of high conjugated bilirubinemia, in addition to a less prominent unconjugated bilirubinemia in these patients may be attributed more to the hepatitis than hemolytic anemia in these patients. Additionally, the unconjugated bilirubin may have caused inspissated bile syndrome, which could also explain the conjugated bilirubinemia in these patients.

Both Cases 1 and 3 had received less than 10 packed erythrocyte transfusions prior to serum ferritin measurement and liver biopsy. The serum ferritin level was extremely high in Case 1 (Table 1) and the liver biopsy also exhibited hemosiderin accumulation. The rapid decline in serum ferritin from $32078 \mathrm{ng} / \mathrm{ml}$ to $4858 \mathrm{ng} / \mathrm{ml}$ after intensification of immunosuppressive treatment may indicate that the high serum ferritin level in this patient reflects the severity of inflammation. Hyperferritinemia may also be related to the prior transfusions and may also exacerbate the underlying hepatitis in the presence of iron accumulation in the liver. The serum ferritin level of Case 3 was $93 \mathrm{ng} / \mathrm{ml}$, without any evidence of hemosiderin accumulation in the liver biopsy, and this patient was the only one to survive. Serum ferritin was measured as $325 \mathrm{ng} / \mathrm{ml}$ in Case 2 , without any evidence of iron accumulation in the liver. The previously reported case of Akyildiz et al. [3] was reported to have a pre-transplantation serum ferritin level of $3236 \mathrm{ng} / \mathrm{ml}$ and their patient survived after liver transplantation. These findings may indicate that lower serum ferritin levels can predict the responsiveness to immunosuppressive treatment, and as a consequence, the better outcome in some patients; it may also explain the clinical heterogeneity of the GCH-AlHA. Case 1, who had very high serum ferritin levels, had a poor course in spite of immunosuppression, whereas Case 3, who had lower initial serum ferritin levels, responded well to treatment. However, Case 2, who had a moderate increase in ferritin, did not have the opportunity to receive immunosuppressive treatment; thus, it is not possible to draw a conclusion about the relationship between his serum ferritin and the treatment response-outcome. Additionally, CMV infection might also have contributed to the higher serum ferritin levels and poorer outcomes in Cases 1 and 2, compared to the CMV-negative Case 3. While the sample size is limited for making a definitive conclusion, if this observation is confirmed with further studies with increased numbers of patients, serum ferritin may be used to predict which patients may benefit from immunosuppressives and those which may require more aggressive approaches, including earlier transplantation. This would also help to decrease the deaths related to the prolonged use of immunosuppressives.

\section{Conflict of interest}

No author of this paper has a conflict of interest, including specific financial interests, relationships, and/or affiliations relevant to the subject matter or materials included in this manuscript.

\section{References}

1. Gorelik M, Debski R, Frangoul H. Autoimmune hemoIytic anemia with giant cell hepatitis: case report and review of the literature. J Pediatr Hematol Oncol 2004;26:837-9.

2. Melendez HV, Rela M, Baker AJ, Ball C, Portmann B, Mieli-Vergani G, Heaton ND. Liver transplant for giant 
cell hepatitis with autoimmune hemolytic anemia. Arch Dis Child 1997; 77:249-51.

3. Akyildiz M, Karasu Z, Arikan C, Nart D, Kilic M. Successful liver transplantation for giant cell hepatitis and Coombs-positive hemolytic anemia: a case report. Pediatr Transplant 2005; 9:630-3.

4. Rovelli A, Corti P, Beretta C, Bovo G, Conter V, MieliVergani G. Alemtuzumab for giant cell hepatitis with autoimmune hemolytic anemia.J Pediatr Gastroenterol Nutr 2007;45:596-9.

5. Miloh T, Manwani D, Morotti R, Sukru E, Shneider B, Kerkar N. Giant cell hepatitis and autoimmune hemoIytic anemia successfully treated with rituximab. J Pediatr Gastroenterol Nutr 2007;44:634-6.

6. Perez-Atayade AR, Sirlin SM, J onas M. Coombs-positive autoimmune hemolytic anemia and post-infantile giant cell hepatitis in children. Pediatr Pathol 1994;14:69-77.

7. Hartman C, Berkowitz D, Brik R, Arad A, Elhasid R, Shamir R. Giant cell hepatitis with autoimmune hemoIytic anemia and hemophagocytosis. J Pediatr Gastroenterol Nutr 2001;32:330-4.

8. Kehrli ME J r, Goff JP, Stevens MG, Boone TC. Coombs positive giant cell hepatitis-a new feature of Evans' syndrome. Arch Dis Child 1998;78:397-8.

9. Weinstein T, Valderrama E, Pettei M, Levine J. Early steroid therapy for the treatment of giant cell hepatitis with autoimmune hemolytic anemia. J Pediatr Gastroenterol Nutr 1993;17:313-6.

10. Imgrueth M, Wagner HP, Pipczynski-Suter K, Beguin L, Wyss M, Pfister AM, Stock HK, Oetliker O.Plasma exchange: an important part of the therapeutic proce- dure in a small child with autoimmune hemolytic anemia. Acta Paediatr Scand 1986;75:1037-41.

11. Kashyap R, Sarangi J N, Choudhry VP. Autoimmune hemolytic anemia in an infant with giant cell hepatitis. Am J Hematol 2006;81:199-201.

12. Choulot JJ, Parent Y, Etcharry F, Saint-Martin J , Mensire A. Giant cell hepatitis and autoimmune hemolytic anemia: efficacy of splenectomy on hemolysis. Arch Pediatr 1996;3:789-91.

13. Vajro P, Migliaro F, Ruggeri C, Di Cosmo N, Crispino G, Caropreso M, Vecchione R. Life saving cyclophosphamide treatment in a girl with giant cell hepatitis and autoimmune haemolytic anaemia: case report and upto-date on therapeutical options. Dig Liver Dis 2005;38:846-50.

14. Bernard $\mathrm{O}$, Hadchouel M, Scotto J, Odièvre M, Alagille D. Severe giant cell hepatitis with autoimmune hemoIytic anemia in early childhood. J Pediatr 1981;99: 704-11.

15. Brichard B, Sokal E, Gosseye S, Buts JP, Gadisseux J F, Cornu G. Coombs-positive giant cell hepatitis of infancy: effect of steroids and azathioprine therapy. Eur J Pediatr 1991;150:314-7.

16. Camarero Salcés C, Vasconez Muñoz F, San José Hernando D, Morales P, Suárez Cortina L, Parra Vázquez C, Escobar Castro H, Muñoz Villa A. Autoimmune hemolytic anemia associated with severe giant cell hepatitis. An Esp Pediatr 1991;34:149-51.

17. Pappo O, Yunis E, J ordan JA, J affe R, Mateo R, Fung J, Demetris AJ . Recurrent and de novo giant cell hepatitis after orthotopic liver transplantation. Am J Surg Pathol 1994;18:804-13. 